\title{
A novel adenovirus E1B19K-binding protein B5 inhibits apoptosis induced by Nip3 by forming a heterodimer through the $\mathrm{C}$-terminal hydrophobic region
}

\author{
Naoto Ohi ${ }^{1}$, Akinori Tokunaga ${ }^{2}$, Haruki Tsunoda ${ }^{1}$, \\ Kazuhiro Nakano ${ }^{1}$, Keiko Haraguchi ${ }^{1}$, Kinichiro Oda ${ }^{1}$, \\ Noboru Motoyama ${ }^{2}$ and Takuma Nakajima ${ }^{*, 1,3}$ \\ ${ }^{1}$ Department of Biological Science and Technology, Science University of \\ Tokyo, Noda, Japan \\ 2 Department of Molecular Immunology, Medical Institute of Bioregulation, \\ Kyushu University, Fukuoka, Japan \\ ${ }^{3}$ Current address: Department of Molecular Cellular Oncology and \\ Microbiology, Faculty of Dentistry, Tokyo Medical Dental University, Tokyo, \\ Japan \\ * corresponding author: Department of Molecular Cellular Oncology and \\ Microbiology, Faculty of Dentistry, Tokyo Medical Dental University 1-5-45 \\ Yushima, Bunkyo-Ku, Tokyo 113-8549, Japan. tel: +81(0)3-5803-5458 \\ fax: +81(0)3-5803-0189, e-mail: nakajima.mco@dent.tmd.ac.jp
}

Received 16.7.98; revised 13.11.98; accepted 17.12.98 Edited by Y. Kuchino

\begin{abstract}
The adenovirus E1B19K protein inhibits apoptosis induced by E1A and other divergent signals. The cellular proteins that interact with E1B19K have been analyzed by isolating CDNA clones by the yeast two hybrid system. One of these clones encodes B5 which consists of 219 amino acid residues and contains the putative $\mathrm{BH} 3$ and transmembrane regions. B5 binds strongly to Nip3 and itself, weakly to E1B19K, but not to $\mathrm{Bcl}-2$ and localizes in nuclear envelope, endoplasmic reticulum and mitochondria. B5 has sequence homology with Nip3 in the middle and C-terminal regions, but not in the $\mathrm{N}$ terminal region. Unlike other $\mathrm{E} 1 \mathrm{~B} 19 \mathrm{~K}$ binding $\mathrm{BH} 3$ proteins so far characterized, B5 does not induce apoptosis, but inhibits apoptosis induced by Nip3. However the deletion mutant B5 $\Delta 1-31$ lacking the $\mathrm{N}$-terminus does induce apoptosis, although weaker than does Nip3, suggesting that the Nterminal region is masking the apoptosis-inducing capacity of B5.
\end{abstract}

Keywords: apoptosis; E1A; E1B19K binding protein B5; Nip3

Abbreviations: AT, aminotriazole; $\mathrm{BH}, \mathrm{Bcl}-2$ homology; FCS, fetal calf serum; NP40, Nonidet P40; PBS, phosphate buffered saline; PMSF, phenylmethylsulfonyl fluoride

\section{Introduction}

The adenovirus $\mathrm{E} 1 \mathrm{~A}$ gene product $\mathrm{E} 1 \mathrm{~A}$ has abilities to induce cell proliferation and death and to inhibit cell differentiation depending on cellular factors to which it interacts. The E1B19K protein (E1B19K) encoded by the adjacent E1B gene suppresses E1A-induced apoptosis and facilitates viral growth in the infected cells $s^{1,2}$ and transformation of primary rodent cells by $\mathrm{E} 1 \mathrm{~A} .^{3,4} \mathrm{E} 1 \mathrm{~B} 19 \mathrm{~K}$ shares limited sequence homology with $\mathrm{Bcl}-2$ and with other $\mathrm{Bcl}-2$ family members within $\mathrm{Bcl}-2$ homology region $(\mathrm{BH}) 1$ and just before $\mathrm{BH} 2^{5,6}$ and inhibits apoptosis induced by tumor necrosis factor $\alpha$ and Fas ligand even more efficiently than does Bcl-2. ${ }^{3,6-8}$

E1B19K has been shown to interact with and disrupt the organization of intermediate filaments and modify the structure of nuclear laminA and laminC. ${ }^{9}$ The cDNA clones encoding the E1B19K-binding proteins Nip1, Nip2, Nip3, ${ }^{5}$ Bax, Bak ${ }^{10-14}$ and $\mathrm{Nbk} / \mathrm{Bik}^{15,16}$ have been isolated by the yeast two hybrid system. Bax and Bak are the members of the Bcl-2 family, but, unlike $\mathrm{Bcl}-2$ and $\mathrm{Bcl}-\mathrm{XL}$, they are inducers of apoptosis. Most of the Bcl-2 family members share $\mathrm{BH} 1, \mathrm{BH} 2$ and $\mathrm{BH} 3$ and the $\mathrm{C}$-terminal transmembrane region which directs their localization to mitochondrial outer membrane, nuclear envelope and endoplasmic reticulum. ${ }^{17-19}$ Among Nip1, Nip2 and Nip3, Nip3 has been shown to be a dimeric mitochondrial protein and to induce apoptosis in Rat-1 fibroblasts and MCF-7 breast carcinoma. ${ }^{20} \mathrm{Nbk} / \mathrm{Bik}$ is also a potent stimulator of apoptosis. ${ }^{16}$ Both Nip3 and Nbk/Bik lack $\mathrm{BH} 1$ and $\mathrm{BH} 2$, but contain putative $\mathrm{BH}$. A Nip3 mutant lacking the $\mathrm{C}$ terminal transmembrane domain loses the ability to dimerize, localize to mitochondria and induce apoptosis. ${ }^{20}$

We have previously established a cell line MA1 from human epidermoid carcinoma cells $\mathrm{KB}$ by introducing the adenovirus type 2 E1A $12 S$ cDNA linked to the mouse mammary tumor virus long terminal repeat (MMTV-LTR). MA1 cells express E1A12S in response to dexamethasone (dex) and undergo apoptosis after stabilization of wild type (wt) p53 and degradation of topoisomerase $\mathrm{Il} \alpha$ through modification of the ubiquitin-proteasome pathway. ${ }^{21,22}$ Both induction of apoptosis and degradation of topoisomerase Il $\alpha$ were inhibited by the E1B19K and $\mathrm{Bcl}-2$ in a dosedependent manner.

To analyze the role of E1B19K in the suppression of apoptosis in MA1 cells, cDNAs encoding the E1B19Kbinding proteins have been isolated by using the yeast two hybrid system. The B5 protein encoded by one of these clones contains putative $\mathrm{BH} 3$ and transmembrane domains in the middle and C-terminal regions, and localizes to nuclear envelopes, endoplasmic reticulum and mitochondria. B5 has sequence homology with Nip3 in these regions, but has unique sequence in the $\mathrm{N}$-terminal region. B5 itself has no ability to induce apoptosis, but rather inhibits apoptosis induced by Nip3 in KB cells. However, B5 is capable of inducing apoptosis when it lacks the $\mathrm{N}$ terminal region, although the extent of apoptosis induced is smaller than that induced by Nip3. These results suggest that B5 is a unique negative regulator of 
apoptosis among the $\mathrm{E} 1 \mathrm{~B} 19 \mathrm{~K}$ binding $\mathrm{BH} 3$ proteins and its capacity to induce apoptosis is masked by the $\mathrm{N}$-terminal region.

\section{Results \\ Isolation of CDNA clones encoding E1B19K- binding proteins by the yeast two hybrid system}

To analyze the biological function of E1B19K to inhibit apoptosis induced by E1A in MA1 cells in a dose-dependent manner, the cDNA clones encoding E1B19K binding proteins were isolated by the yeast two hybrid system. Tester strains were established from yeast strains HF7C and Y190 by introducing pGBT-B19 which express a fusion protein composed of Gal4 DNA binding domain and E1B19K. A cDNA library was constructed from MA1 cells in the pGAD424 vector, which directs the synthesis of fusion proteins composed of cDNA-encoded polypeptides and the Gal4 transcriptional activation domain. The tester strains HF7C-19K and Y190-19K were transformed with the pGADMA1 cDNA library and plated on medium lacking histidine. $\mathrm{His}^{+}$colonies developed (about 250 clones) were then tested for production of $\beta$-galactosidase by an X-Gal filter assay. Thirty-two clones were finally selected and cDNA sequences of these clones were partially determined by using the primer which anneal within the 3 '-end portion of the Gal4 activation domain. The cDNAs were classified into five groups and one to two representative cDNAs in each group were recloned into pBluescript $\mathrm{KS}(+)$ and sequenced. Twenty-six clones were either laminA or laminC, two each clones contained Bak and novel sequences and one each clone was Nip2 and Nip3. The two clones containing novel sequences were turned out to be the same and the protein encoded was termed B5.

B5 cDNA comprises 1526 base pairs (bp) and contains a continuous open reading frame of 219 amino acids (aa) (Figure 1A). No B5 cDNA clones that contain longer coding sequence could be isolated from a MA1 cell cDNA library constructed with the $\lambda$ Zapll expression vector. The first ATG codon has the Kozak motif and the protein encoded was efficiently expressed, when the cDNA was cloned in an expression vector as shown in later sections. B5 has high aa sequence homology with the E1B19Kbinding protein Nip3 in the middle and $\mathrm{C}$-terminal regions as shown by underlines in Figure $1 \mathrm{~A}$, but has the unique sequence in the $\mathrm{N}$-terminus from positions $1-34$. The amino acid sequences of B5 and Nip3 within these homologous regions are compared in Figure 1B. More than $80 \%$ of the B5 amino acid residues from positions 60-96 are identical or functionally-related with the corresponding residues of Nip3. $\mathrm{B} 5$ has no $\mathrm{BH} 1$ and $\mathrm{BH} 2$ domains, but has the $\mathrm{BH} 3$-like domain from positions 130-144. The amino acid residues of B5 within this domain differ considerably from those of Nip3 and the Bcl2 family members, but the critical amino acids, leucine ${ }^{134}$, aspartic acid ${ }^{139}$ and valine ${ }^{141}$ instead of isoleucine are conserved as compared with the $\mathrm{BH} 3$ domain of Bak. ${ }^{23}$ The hydropathy plots predicted that the aa sequence from positions $176-204$ is a membrane-spanning region which is characteristic of the Bcl-2 family members. The amino acid residues of $\mathrm{B} 5$ within this putative transmembrane region are identical or functionally-related with those of Nip3 except one residue. A search of the protein data base (GenBank, accession number 2511529) with the B5 sequence revealed that B5 was listed in a group of genes expressed in an infant brain.

\section{Interaction of B5 with other E1B19K-binding proteins in yeasts}

To see the interaction of B5 with other E1B19K-binding proteins, pGAD424 expression vectors encoding the Gal4 transactivation domain fused to laminA, laminC, Nip2, Nip3, $\mathrm{Bak}, \mathrm{Bcl}-2$ or $\mathrm{B} 5$ were constructed. Each of these vectors were introduced into HF7C yeast cells with the pGBT9 expression vector encoding the Gal4 DNA binding domain fused to B5 and the transformants were streaked on S.D. medium lacking histidine, but containing $3 \mathrm{mM}$ 3-AT. Under the conditions, the growth was dependent on the interaction of B5 with the other E1B19K-binding proteins. The result is summarized in Figure 2A. B5 showed strong interaction with Nip2, Nip3 and B5 itself, but no interaction with Bak and Bcl-2. Nip2 and Nip3 interacted strongly with $\mathrm{Bcl}-2$ as previously reported. ${ }^{5} \mathrm{~B} 5$ interacted weakly with $\mathrm{E} 1 \mathrm{~B} 19 \mathrm{~K}$ and laminC, but not with laminA, although E1B19K interacts strongly with laminA and laminC.

The B5 mutant lacking the $C$ terminus $(\Delta 170-219)$ could not interact with E1B19K, Nip3 and B5 itself (Figure 2B), suggesting that the interaction requires the putative transmembrane region. The B5 mutant lacking codons 58-96 interacted with Nip3 and B5 itself but not with E1B19K, indicating that the middle region having high sequence homology to Nip3 is also required for interaction with E1B19K. The interaction of E1B19K and B5 was similarly analyzed with E1B19K mutants containing a deletion either in the $\mathrm{N}$-terminus $(\Delta 1-22)$ or in the middle region $(\Delta 90-96)$ that are essential for suppression of the E1A-induced apoptosis. These mutants were unable to interact with B5, however, a point mutation at the aa residue 82 (DY), which also abolish the E1B19K suppressive activity $^{24}$ had no effect on the interaction of E1B19K with B5. Interaction of B5 with Nip3 and E1B19K was also analyzed by $\beta$-galactosidase assay (Figure 2D). The $\beta$-galactosidase activities in HF7C cells transformed by pGBT-B5 and pGAD-B5 or pGAD-Nip3 were higher than those in the cells transformed by pGBT-E1B19K and pGAD-B5 or pGAD-Nip3 indicating that the interaction of B5 with Nip3 and B5 itself is stronger than that of E1B19K with Nip3 and B5. The result obtained is consistent with that obtained by the histidine selection.

\section{Homo- and hetero-dimerization of B5 in vivo}

To see homo- and hetero-dimerization of B5 in vivo and to determine the domain required for dimerization, the expression vector pCXN-FB5 encoding Flag epitope-tagged B5 (FB5) was used to transfect COS7 cells, since the vector contains the SV40 ori and multiplicates in COS7 cells expressing SV40 large $\mathrm{T}$ antigen. The vectors, $\mathrm{pCXN}$ - 
FB5 $\Delta C$ encoding $B 5$ lacking the $C$-terminus $(\Delta 188-219)$ and pCXN-FB5 $\Delta N M$ lacking the $\mathrm{N}$-terminal and middle regions $(\Delta 1-119)$ were similarly transfected (Figure $3 A)$. The lysates prepared at $20 \mathrm{~h}$ after transfection were analyzed by Western blotting with anti-Flag antibody. Two proteins of 35 and $70 \mathrm{kDa}$ that correspond to monomeric and dimeric form of B5

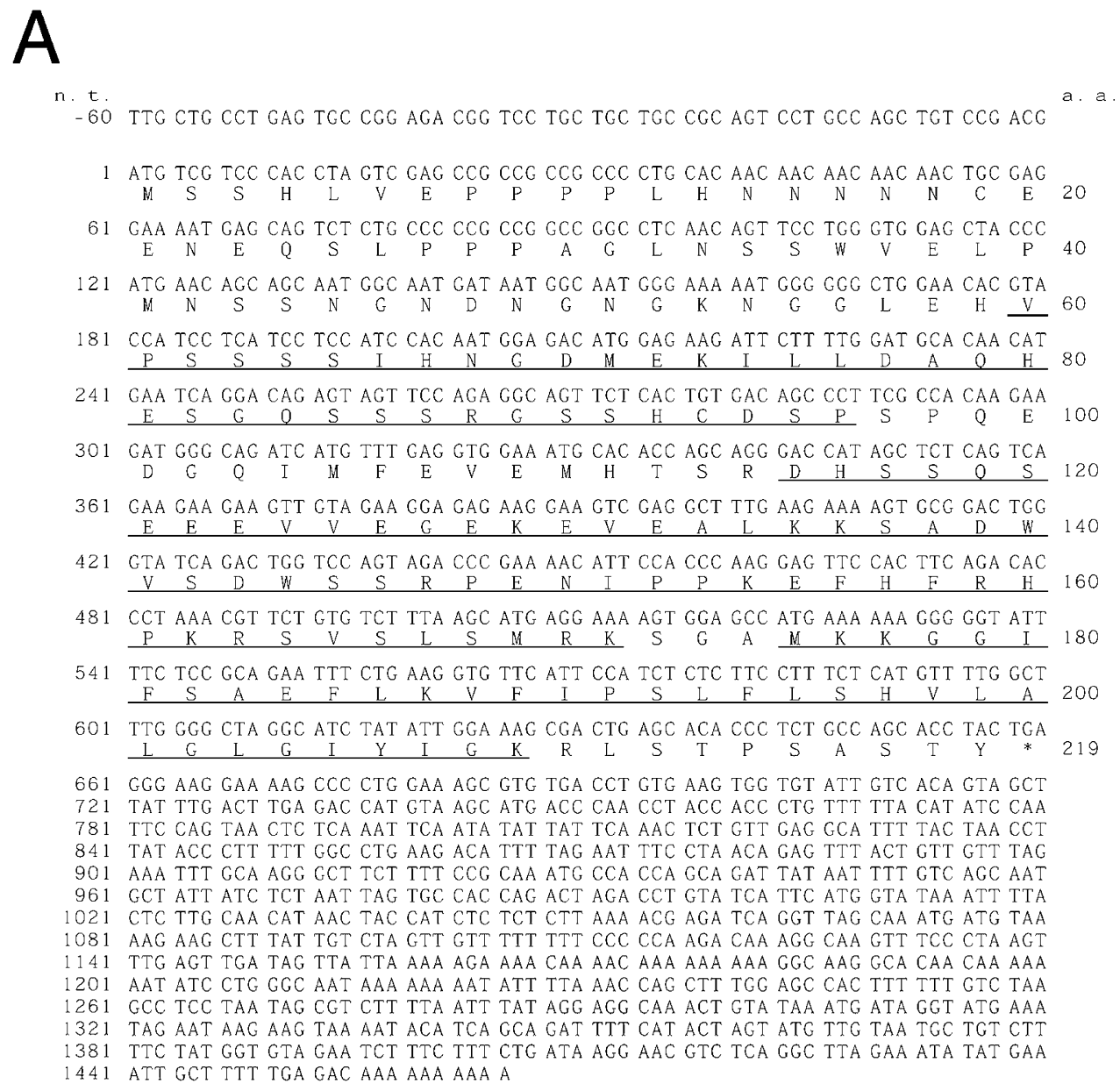

$\mathrm{B}$

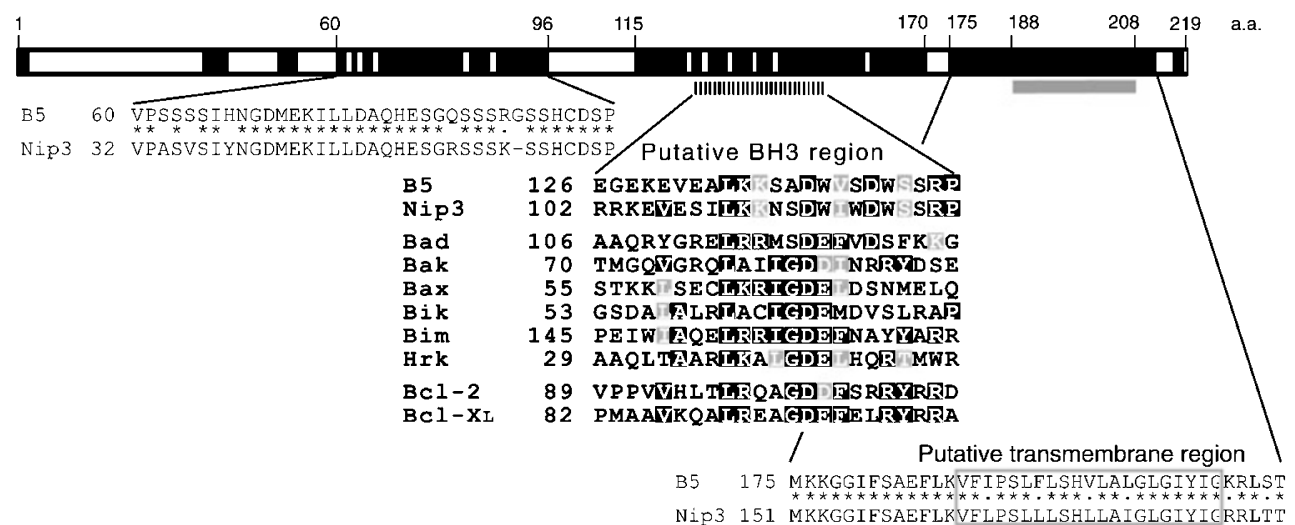

Figure 1 Structural features of B5. (A) Nucleotide sequence and the predicted amino acid (aa) sequence of B5. The aa sequences highly homologous with those of Nip3 are underlined. (B) Comparison of amino acid sequences between B5 and Nip3 within the highly homologus regions. The B5 sequences from positions $60-$ 96, from positions 115-170 containing putative $\mathrm{BH} 3$ domain and from positions 175-213 containing putative transmembrane region are compared with the corresponding sequences of Nip3. The amino acid residues that are identical are shown by stars and those that are functionally-related are shown by dots. The B5 putative $\mathrm{BH} 3$ sequence is also compared with the $\mathrm{BH} 3$ core sequences of the Bcl-2 family members. ${ }^{28}$ The identical residues are black-boxed and functionally related residues are dark-boxed 
A
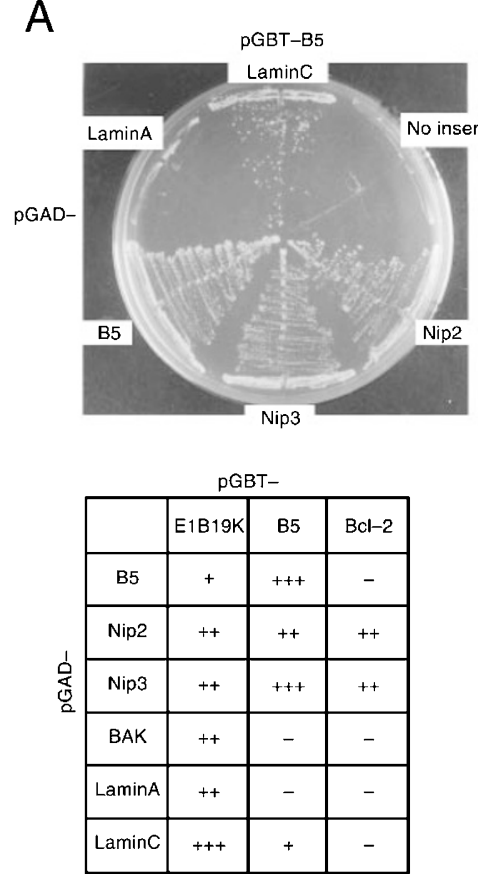

B
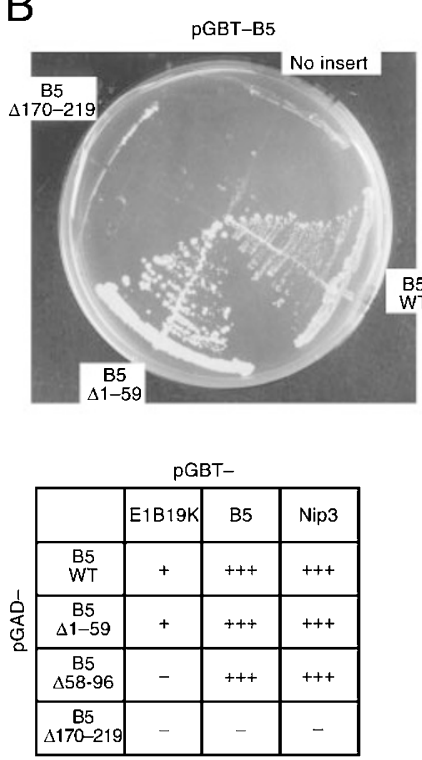

C
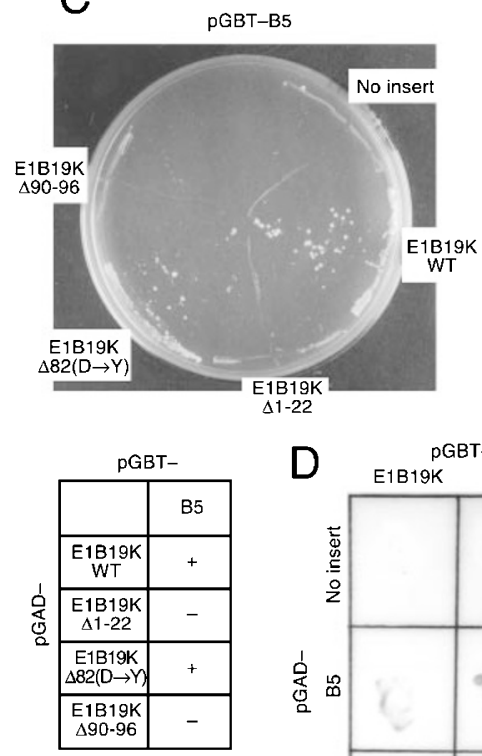

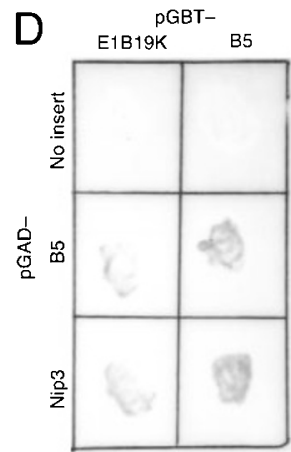

Figure 2 Interaction of B5 with E1B19K binding proteins in yeast strain HF7C. (A) The pGBT9 expression vector encoding the Gal4 DNA binding domain fused to B5 was transformed with the pGAD424 expression vectors encoding the Gal4 transactivation domain fused to either Nip2, Nip3, B5, Bak, Bcl-2, laminA or laminC as indicated. The transformants grown on plates containing histidine but lacking leucine and tryptophan were streaked on plates not containing histidine but containing $3 \mathrm{mM} 3 \mathrm{AT}$. A part of the result showing the growth of colonies is shown above. Interaction of E1B19K and Bcl-2 with the E1B19K binding proteins was similarly analyzed as controls and the results obtained are summarized in the Table shown below. The affinity of binding shown is as follows; +++, very strong affinity; ++, strong affinity; +, weak affinity; -, no affinity. (B) Interaction of B5 mutants with E1B19K binding proteins. The pGBT9 expression vectors for B5 deletion mutants fused to the Gal4 DNA binding domain were introduced with the pGAD424 expression vectors encoding the fusion proteins of E1B19K, B5 or Nip3 into yeast strain HF7C, and the interaction was analyzed similarly as described in A. (C) Interaction of B5 with E1B19K deletion mutations. The interaction was similarly analyzed. (D) pGBT-B5 and pGBT-E1B19K were cointroduced with pGAD-B5 and pGAD-Nip3 into HFC7 cells as indicated. Colonies developed were streaked on the filter placed on S.D., His ${ }^{-}$, 3AT agar medium and assayed for $\beta$-galactosidase after incubation for 2 days

were detected in FB5 lysate. In FB5 $\triangle$ NM lysate, two proteins of 15 and $30 \mathrm{kDa}$ were detected. These sizes just correspond to the monomeric and dimeric form of the $\mathrm{C}$-terminal half of B5. Only one protein of $32 \mathrm{kDa}$, which corresponds to B5 lacking the $\mathrm{C}$-terminus, was detected in $\mathrm{FB} 5 \Delta \mathrm{C}$ lysate. The result suggests that B5 dimerizes in vivo through the Cterminal transmembrane region. Essentially the same result was obtained with 293T cells expressing SV40 large T antigen (data not shown).

Hetero-dimerization of B5 with Nip3 in vivo was similarly analyzed by immunoprecipitation-Western blot analysis (Figure 3B, top). COS7 cells were transfected with pCXN-FB5, pCXN-HA-Nip3 or both. pCXN-HA-Nip3 encodes HA epitope-tagged Nip3. The lysates prepared at $24 \mathrm{~h}$ after transfection were first blotted with anti-HA antibody which detects the presence of Nip3. In Nip3 lysate, Nip3 was detected as two bands of 30 and $60 \mathrm{kDa}$. Although a predicted molecular mass of Nip3 is $21.5 \mathrm{kDa}$ (194 aa), these bands are likely to correspond to a Nip3 monomer and a dimer as also observed by Chen et al. ${ }^{19}$ An additional band of $65 \mathrm{kDa}$ was detected in the $\mathrm{B} / \mathrm{N}$ lysate prepared from the cells transfected with B5 and Nip3 expression vectors. The band seems to correspond to the B5/Nip3 heterodimer, because the molecular mass of B5 (219 aa) is slightly larger than that of Nip3. No Nip3 was detected in the B5 lysate. Analysis of the immunoprecipitates prepared from the $\mathrm{B} / \mathrm{N}$ lysate with anti-Flag antibody by Western blotting with anti-HA antibody revealed three specific bands of 30,60 and $65 \mathrm{kDa}$. None of these bands were detected in the immunoprecipitates prepared from the B5 and Nip3 lysates. The 65 and $60 \mathrm{kDa}$ proteins correspond to the B5/Nip3 heterodimer and the Nip3/Nip3 homodimer. The Nip3/Nip3 homodimer might be coprecipitated with the B5/ B5 homodimer and/or the B5/Nip3 heterodimer. The $30 \mathrm{kDa}$ protein corresponds to the Nip3 monomer which might be generated by dissociation of the B5/Nip3 heterodimer and/or the Nip3/Nip3 homodimer during immunoprecipitation and Western blotting procedures. To compare the size of putative B5/Nip3 heterodimer with that of B5 homodimer, the immunoprecipitates prepared with anti-Flag antibody were blotted with the same anti-Flag antibody (Figure 3B, bottom). Two proteins of 35 and $70 \mathrm{kDa}$ were detected in the immunoprecipitates prepared from both $\mathrm{B} 5$ and $\mathrm{B} / \mathrm{N}$ lysates but not from the Nip3 lysate. The $35 \mathrm{kDa}$ protein corresponds to the B5 monomer and 
A
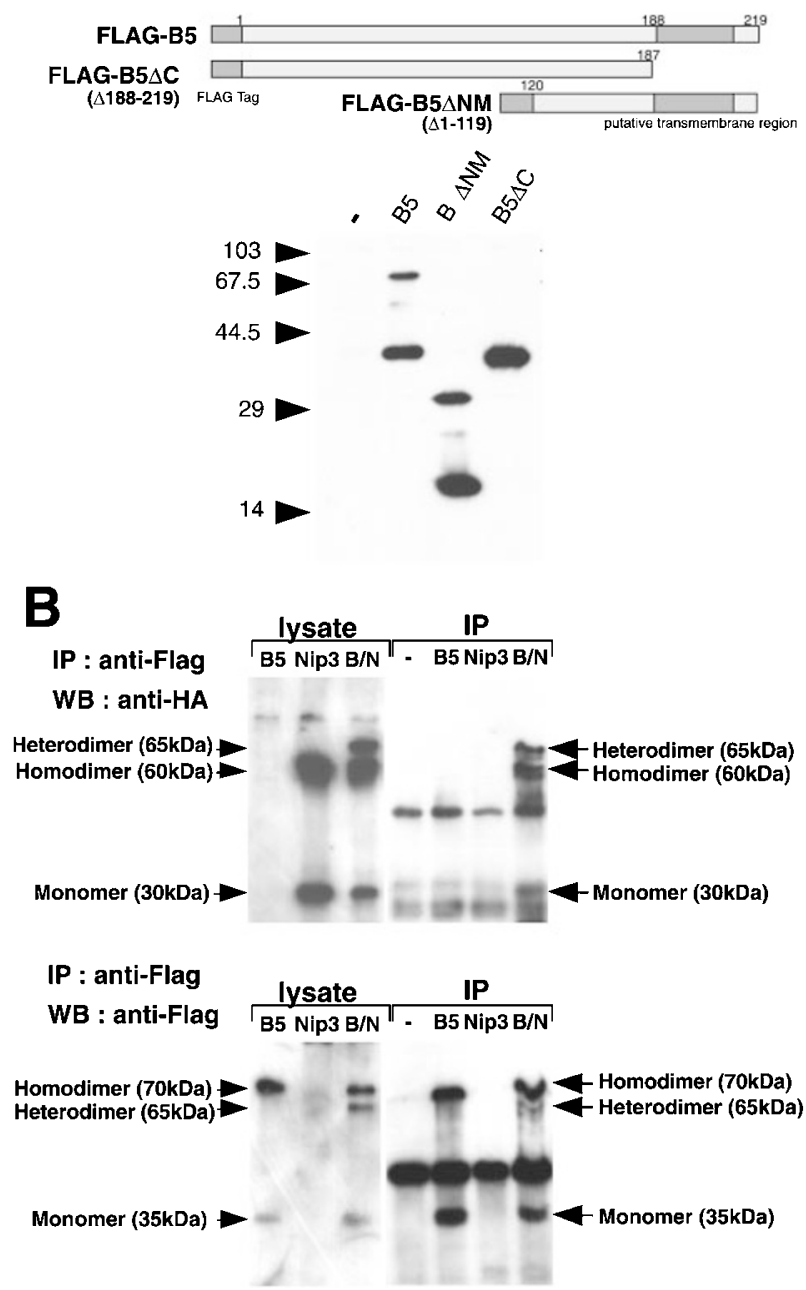

Figure 3 Homo- and hetero-dimerization of B5 in vivo. (A) Homodimerization of $\mathrm{B} 5$. COS7 cells were transfected with the expression vectors, pCXN-FB5, pCXN-FB5 $\Delta N M$ or pCXN-FB5 $\Delta C$, each encoding Flag epitope-tagged B5 or its deletion mutant as shown above. The lysates prepared at $20 \mathrm{~h}$ after transfection were analyzed by Western blotting with anti-Flag mouse monoclonal antibody M5. (B) Heterodimerization of B5 with Nip3. COS7 cells were transfected with pCXN-FB5, pCXN-HA-Nip3 or both and the lysates prepared at $24 \mathrm{~h}$ after transfection were immunoprecipitated with anti-Flag antibody. The immunoprecipitates were analyzed by Western blotting with either anti-HA antibody (top) or with anti-Flag antibody (bottom)

the $70 \mathrm{kDa}$ protein to the B5 homodimer. In addition to these bands, the band of $65 \mathrm{kDa}$, presumably the B5/Nip3 heterodimer, was detected in the $\mathrm{B} / \mathrm{N}$ immunoprecipitate, although its amount was much less than that of the $70 \mathrm{kDa}$ B5/B5 homodimer. The reason is presently unclear, since B5 binds to both Nip3 and B5 itself strongly. These three bands were also detected in the $\mathrm{B} / \mathrm{N}$ lysate by Western blotting. The homo- and hetero-dimerization of B5 is likely to occur through putative transmembrane region. It has been recently shown that LXXLL-containing motifs are required for hydrophobic interaction of two proteins. ${ }^{25} \mathrm{Nip} 3$ contains this motif and B5 contains LXXVL sequence (Figure 1B).

\section{Subcellular localization of B5}

To see the subcellular localization of B5 and to analyze the B5 domain required for interaction with $\mathrm{E} 1 \mathrm{~B} 19 \mathrm{~K}$, both $\mathrm{KB}$ and COS7 cells on cover slips were transfected with either $\mathrm{pCXN}$ FB5, pCXN-FB5 $\Delta$ C or pCXN-FB5 $\Delta$ NM (Figure $3 A$ ) together with the E1B19K expression vector. The cells were fixed at $24 \mathrm{~h}$ after transfection and the localization of B5 and E1B19K was analyzed by indirect immunofluorescence. Anti-Flag mouse monoclonal antibody and anti-E1B19K rabbit polyclonal antibody were used as primary antibodies and visualized with fluorescein and Texas Red-conjugated secondary antibodies, respectively (Figure 4). B5 was expressed in the nuclear envelope/endoplasmic reticulum (ER) region, and in cytoplasmic patches, while E1B19K localized primarily in the nuclear envelope/ER region in both KB (Figure 4A) and COS7 cells (Figure 4B). This different localization of B5 and E1B19K became apparent, when both images were merged to yield yellow color. The yellow color was restricted to the nuclear envelope/ER region, while green color remained in cytoplasmic patches. These patches are typical of a mitochondrial distribution. In contrast, B5 $\Delta \mathrm{C}$ lacking the $\mathrm{C}$-terminal putative transmembrane region localized in the cytoplasm uniformly especially in COS7 cells. Although the intense green color was observed in the nuclear envelope of KB cells, very little yellow color was visible in both $\mathrm{KB}$ and COS7 cells, indicating that $\mathrm{B} 5 \Delta \mathrm{C}$ lost the ability to colocalize with E1B19K. The localization of $\mathrm{B} 5 \Delta \mathrm{NM}$ lacking the $\mathrm{N}$-terminal and middle regions was essentially the same as that of B5.

To confirm the mitochondrial localization of B5, COS7 cells were transfected with pCXN-FB5 and treated with FITC-conjugated MitoTracker which binds to the mitochondrial inner membrane $30 \mathrm{~min}$ prior to fixation. The cells were then stained with anti-Flag mouse monoclonal antibody and Cy3-conjugated anti-mouse IgG. The localization of B5 to mitochondria was evident, since the pattern of Cy3 localization (Figure 5A) was identical with that of MitoTracker (Figure 5B). The overlapping of these images yielded the same pattern of yellow color (Figure $5 \mathrm{C}$ ).

\section{Expression level of Nip3 increased steeply, while that of B5 unchanged during induction of apoptosis in MA1 cells}

To see the changes in expression levels of the gene encoding E1B19K binding proteins during induction of apoptosis in MA1 cells, poly (A)-containing RNAs were prepared from MA1 cells after treatment with dex for various times and aliquots of them were analyzed by Northern blotting (Figure 6). Time course of the apoptotic process in MA1 cells is shown on the top of the Figure. In brief, after induction of E1A expression, p53 stabilizes within $24 \mathrm{~h}$ and topoisomerase $\mathrm{ll} \alpha$ begin to be degraded via the ubiquitin-proteasome pathway. The loss of cell viability begin to be observed subsequently. ${ }^{21,22}$ Two species of B5 mRNA with the lengths of 4.0 and 1.5 kilobases $(\mathrm{kb})$ were detected (Figure $6 \mathrm{Ba}$ ). The levels of these mRNAs, however, remained unchanged during the apoptotic process. The level of Bak mRNA began to increase after $24 \mathrm{~h}$ and increased 2-3-fold at $48 \mathrm{~h}$ (Figure 6Bb). The level of Nip3 
mRNA increased steeply along with the progression of the apoptotic process, reaching a maximal level of more than tenfold higher than the original at $48 \mathrm{~h}$ (Figure 6Bd). The level of laminA mRNA was unchanged, while that of laminC mRNA increased after $36 \mathrm{~h}$ (Figure 6Be). Under the conditions, the level of $\beta$-actin mRNA was unchanged (Figure $6 \mathrm{Bc}$ and $\mathrm{f}$ ).

\section{A KB}

B5

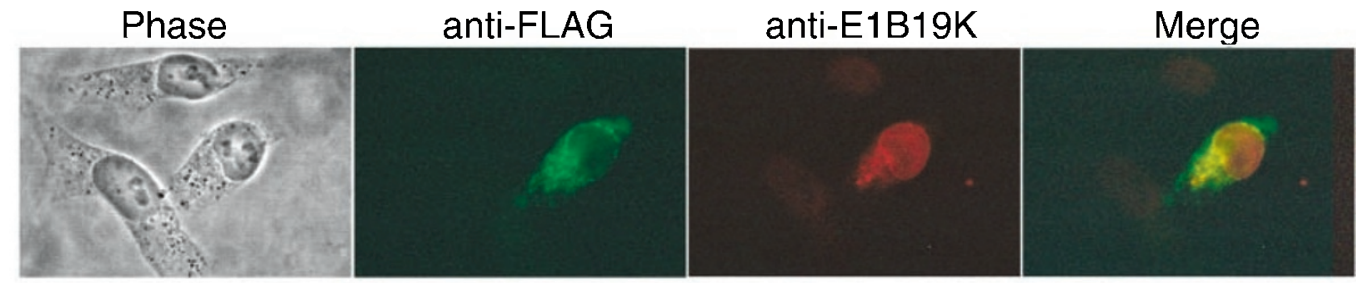

$\mathrm{B} 5 \Delta \mathrm{C}$

$(\Delta 188-219)$
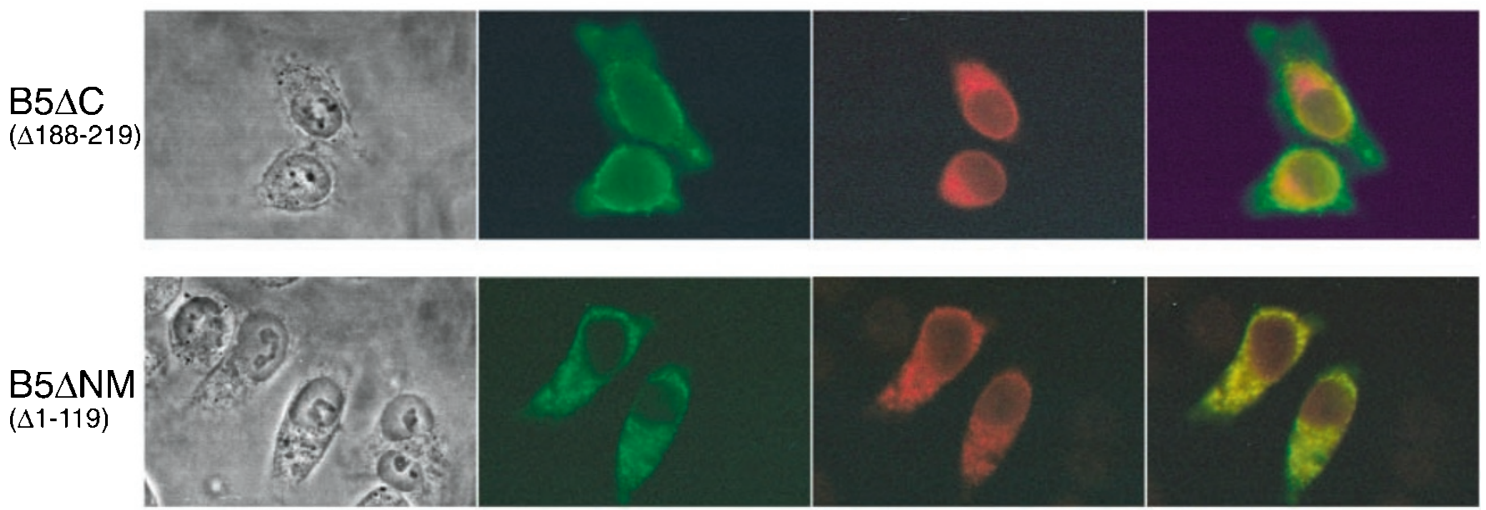

B cos7

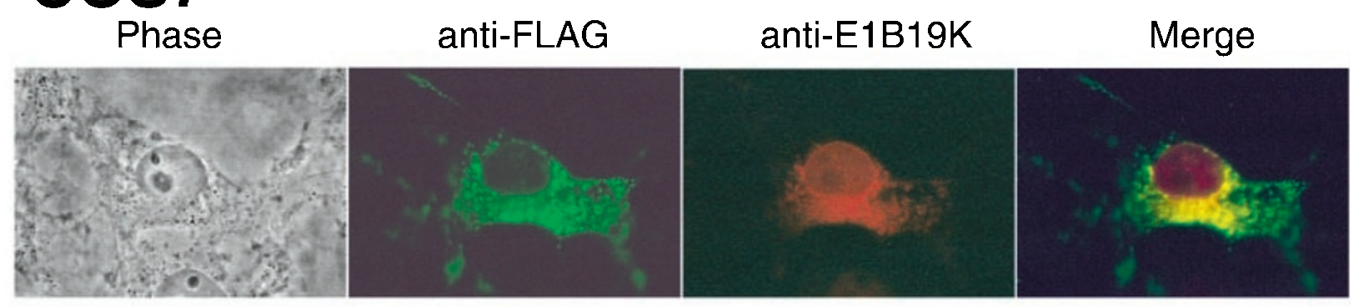

$\mathrm{B} 5 \Delta \mathrm{C}$

$(\Delta 188-219)$
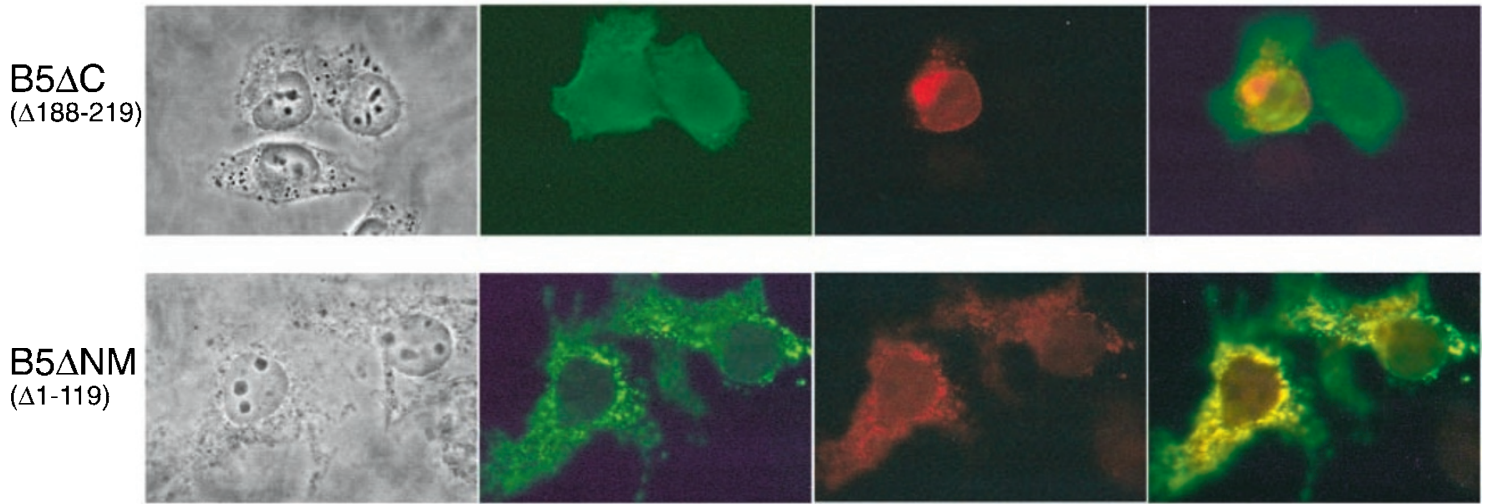

Figure 4 Intracellular localization of $\mathrm{B} 5 . \mathrm{KB}(\mathrm{A})$ and COS7 cells (B) on coverslips were transfected with $\mathrm{pCXN}-\mathrm{FB} 5$, pCXN-FB5 $\triangle \mathrm{C}$, or pCXN-FB5 $\triangle \mathrm{NM}$ together with $\mathrm{pH} \beta \mathrm{APr}-\mathrm{E} 1 \mathrm{~B} 19 \mathrm{~K}$ and fixed at $16 \mathrm{~h}$ after transfection. The cells were permeabilized with $0.1 \%$ Triton $\mathrm{X}$ and incubated with anti-Flag antibody M5 or with antiE1B19K rabbit polyclonal antibody raised against the C-terminal 16 amino acid residues at 1:250 dilutions. The cells were then incubated with FITC-conjugated anti-mouse IgG goat antibody (CAPPEL) or Texas Red-conjugated anti-rabbit IgG donkey antibody (Amersham) at 1:1000 dilutions. Photographs were taken at a magnification of $\times 1000$ 


\section{Inhibitory effect of B5 on the induction of apoptosis by Nip3 is caused through the C-terminal region}

To analyze the ability of B5 to induce apoptosis, KB cells were transfected with the expression vectors for E1A, Nip3, B5 and combinations of these vectors, together with expression vector for CD20, a cell surface calcium binding protein. The apoptotic cells were quantitatively assayed using FACS by the accumulation of cells with DNA of a sub-G1 content earlier after transfection ( $20 \mathrm{~h}$ after transfection) to minimize the development of cell damage caused by transfection (Figure 7 ). The cell damage caused by transfection procedure in control cells $(-)$, to which only the CD20 expression vector
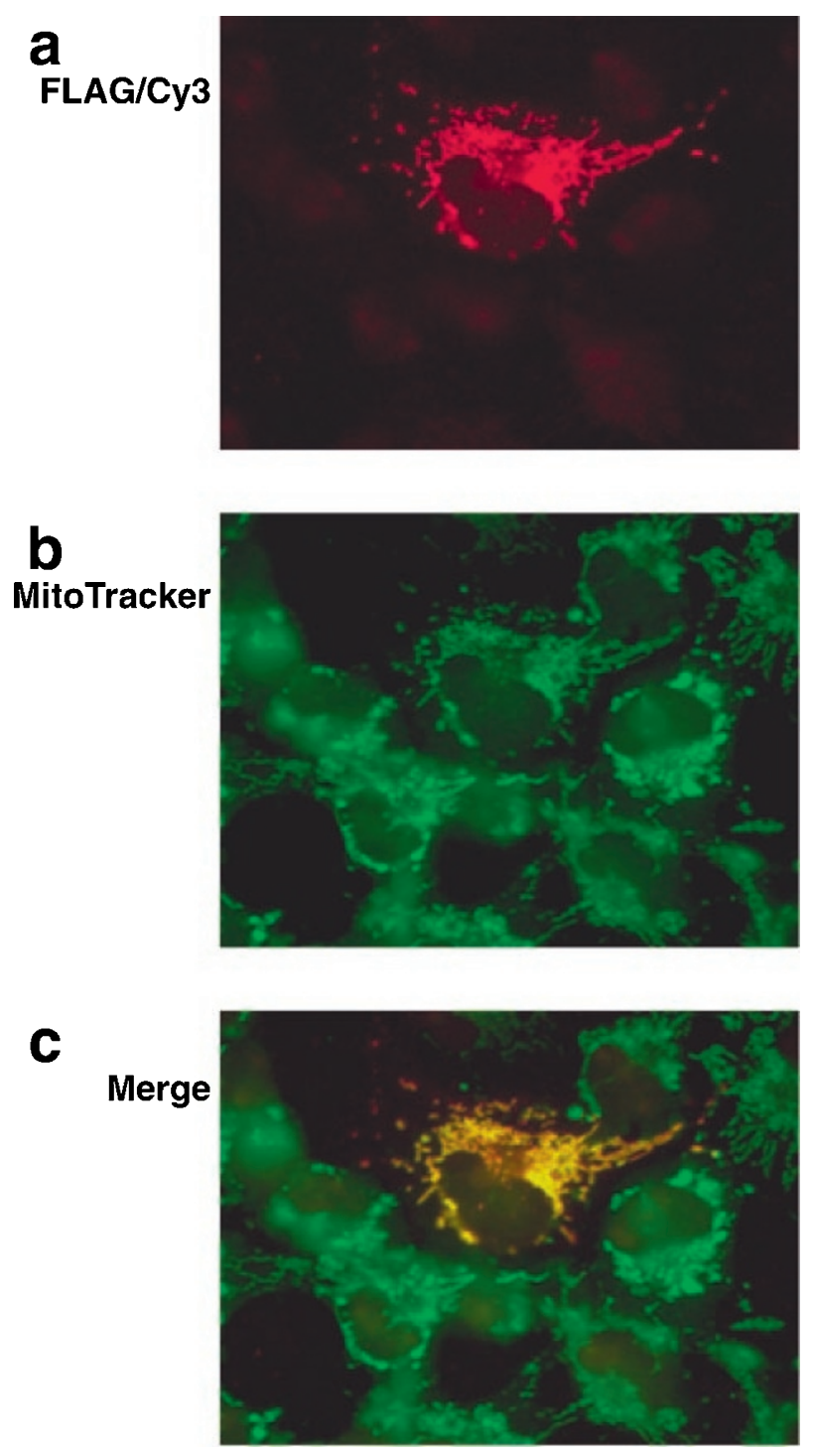

Figure 5 Localization of B5 to mitochondria. COS7 cells were transfected with pCXN-FB5 and stained with FITC-conjugated MitoTracker which binds to the mitochondrial inner membrane (B). The cells were then stained with antiFlag mouse antibody M5 and Cy3-conjugated anti-mouse IgG antibody (A). The above images were combined (C). A uniform yellow color generated indicates the localization of $\mathrm{B} 5$ to mitochondria was transfected (Figure 7Aa), resulted in the increase in the sub-G1 population to $4.1 \%$. The sub-G1 population did not increase significantly by transfection with the B5 expression vector but increased steeply by transfection with the Nip3 expression vector (Figure 7Ab and $c$ ). Transfection with the E1A expression vector resulted in the increase in the sub-G1 population to $10.9 \%$ and this increase was almost unaffected by cotransfection with the B5 expression vector. Cotransfection with expression vectors for E1A and Nip3 (Figure 7Af) showed the sub-G1 increase to $29.8 \%$, but no additive increase was observed, indicating that the action of Nip3

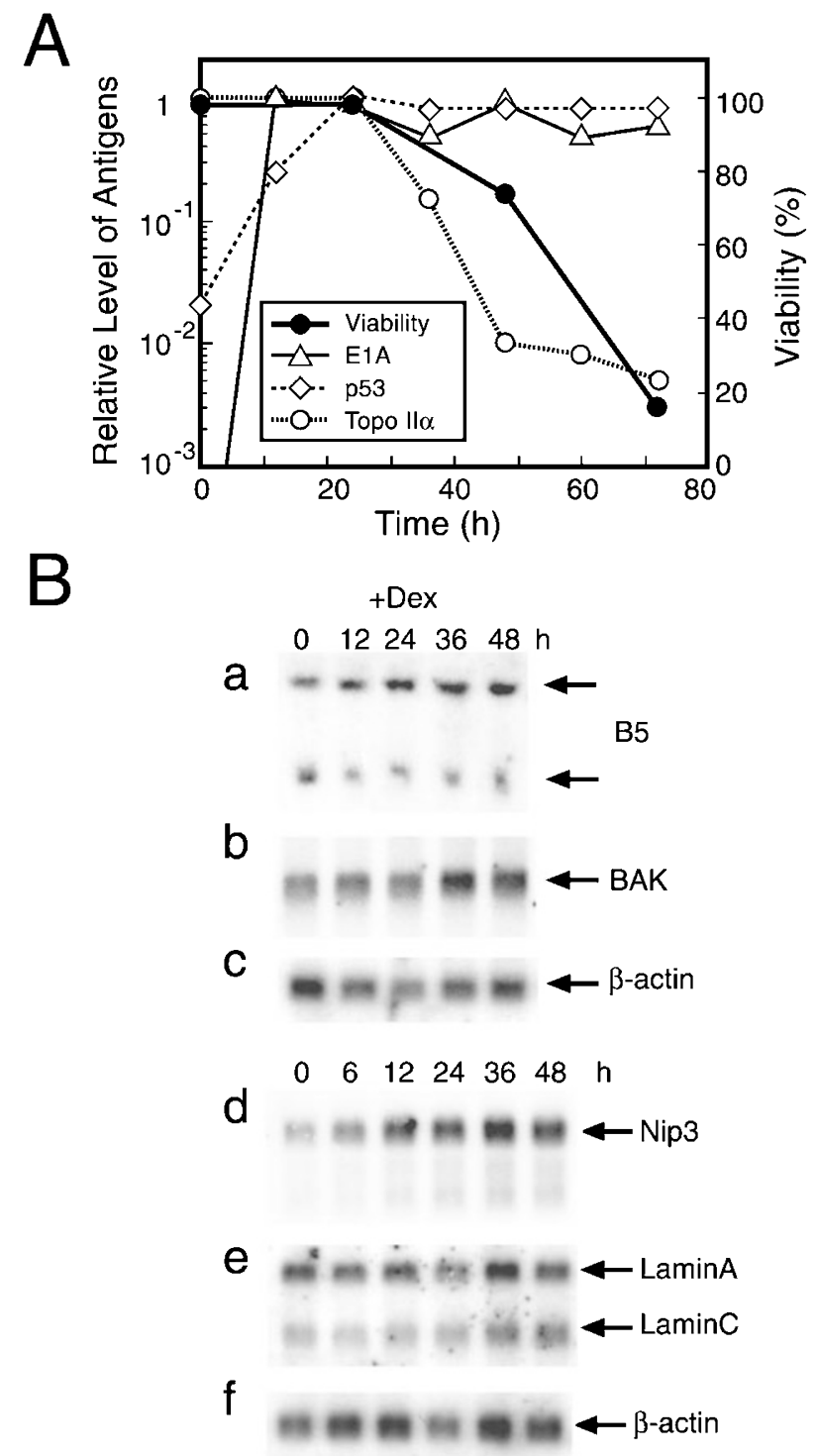

Figure 6 (A) Time course of the induction of apoptosis in MA1 cells after treatment with dex is shown together with those of p53 stabilization and topoisomerase Il $\alpha$ degradation. (B) Poly (A)-containing RNAs were prepared from MA1 cells treated with $1 \mu \mathrm{M}$ dex at the times indicated by using oligotex(dT) $30{ }^{36}$ Aliquots of $3 \mu \mathrm{g}$ of RNAs were electrophoresed and the expression levels of B5 (a), Bak (b), Nip3 (d) and lamin A and C (e) mRNAs were analyzed by Northern blotting with ${ }^{32} \mathrm{P}$-labeled cDNAs as indicated on the right 
predominates over that of $\mathrm{E} 1 \mathrm{~A}$, presumably because the induction of apoptosis by E1A takes longer than does Nip3.
When the cells were cotransfected with expression vectors for $\mathrm{E} 1 \mathrm{~A}$ and $\mathrm{E} 1 \mathrm{~B} 19 \mathrm{~K}$, the increase in the sub-G1 population

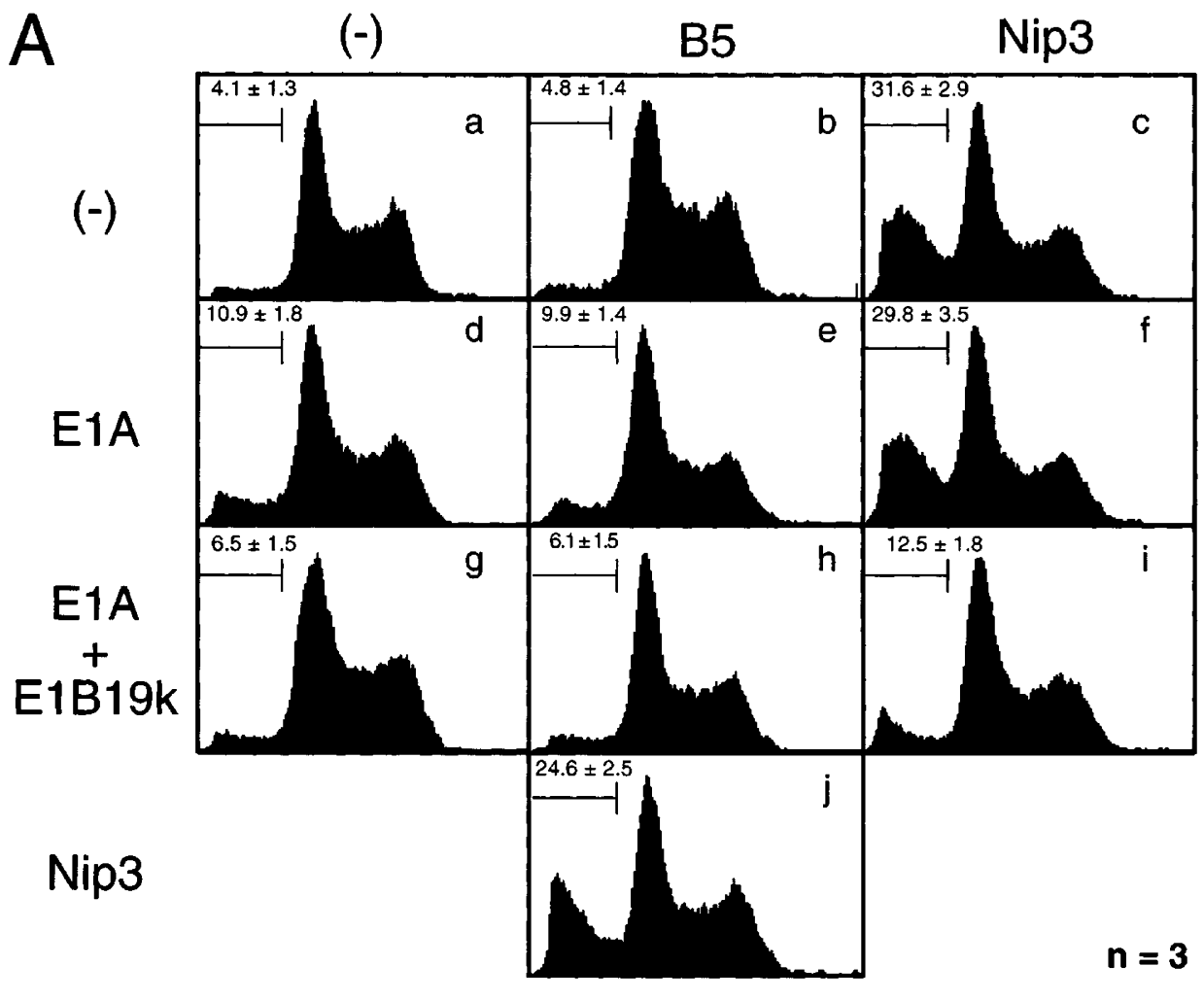

B

$(-)$

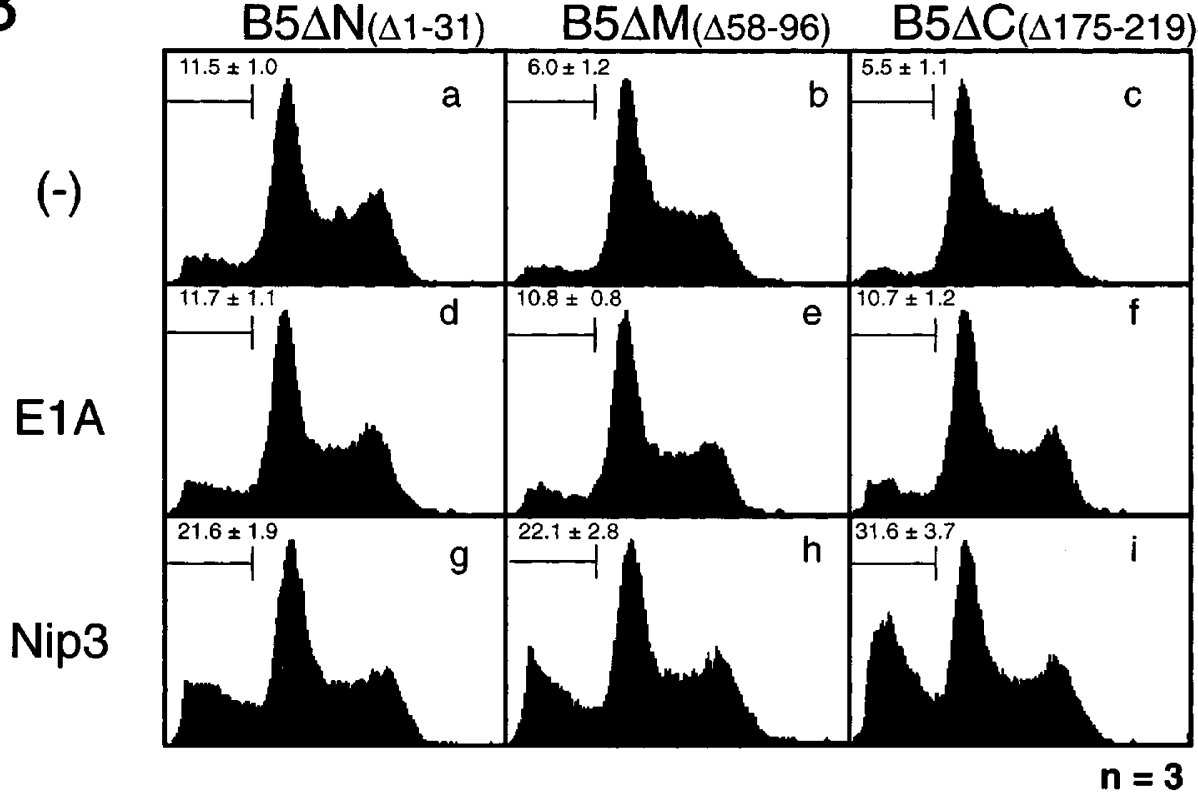

Figure 7 Induction of apoptosis by Nip3 is suppressed by coexpression with B5. (A) Growing cultures of KB cells in $3.5 \mathrm{~cm}$-dishes were transfected with $0.3 \mu \mathrm{g}$ each of the expression vectors, $\mathrm{pH} \beta \mathrm{APr}-\mathrm{B} 5, \mathrm{pH} \beta \mathrm{Apr}-\mathrm{Nip} 3, \mathrm{pH} \beta \mathrm{APr}-\mathrm{E} 1 \mathrm{~A} 12 \mathrm{~S}, \mathrm{pH} \beta \mathrm{APr}-\mathrm{E} 1 \mathrm{~B} 19 \mathrm{~K}$ and combinations of these vectors as indicated together with $0.1 \mu \mathrm{g}$ of pCMV-CD20. A total amount of the vectors was adjusted to $1.0 \mu \mathrm{g}$ per dish with pH $\beta \mathrm{APr}-1$. At $20 \mathrm{~h}$ after transfection, the cells were stained with PI and DNA contents of the cells were analyzed by flowcytometry. The cells were gated based on the expression of CD20. The sub-G1 population was shown as the percentage of the total cell population. The mean values of the three experiments $(n=3)$ are shown with standard deviation. (B) Effect of B5 deletion mutants on E1A- and Nip3induced apoptosis. KB cells were transfected with $\mathrm{pH} \beta \mathrm{Apr}-\mathrm{E} 1 \mathrm{~A} 12 \mathrm{~S}$ or $\mathrm{pH} \beta \mathrm{Apr}-\mathrm{Nip} 3$ together with either $\mathrm{pH} \beta \mathrm{APr}-\mathrm{B} 5 \Delta \mathrm{N}, \mathrm{pH} \beta \mathrm{APr}-\mathrm{B} 5 \Delta \mathrm{M}$ or pH $\beta \mathrm{APr}-\mathrm{B} 5 \Delta \mathrm{C}$ as indicated. DNA contents of the cells were analyzed as described in (A) 
caused by E1A was partially inhibited from 10.9 to $6.5 \%$ (Figure 7Ag). This decrease corresponds to about $65 \%$ inhibition, when calculated after subtraction of the background value, and was unaffected by simultaneous expression of B5 (Figure 7Ah). Nip3 induced apoptosis was also inhibited significantly by E1B19K (Figure 7i). Similar inhibition of Nip3 induced apoptosis by $\mathrm{Bcl}-2$ in Rat-1 cells was observed at early stage of the apoptotic process. ${ }^{20}$ Inhibition of Nip3 induced apoptosis by B5 was weaker than that caused by E1B19K (Figure 7j).

Effects of B5 mutants carrying a deletion in either $\mathrm{N}$ terminal, middle or $\mathrm{C}$-terminal region on the induction of apoptosis by E1A, Nip3 or B5 itself were similarly analyzed by the increase in the sub-G1 population in KB cells (Figure $7 \mathrm{~B}$ ). Among these deletion mutants, $\mathrm{B} 5 \Delta \mathrm{M}$ and $\mathrm{B} 5 \Delta \mathrm{C}$ had no significant activity to induce apoptosis as did wild type $\mathrm{B} 5$ (Figure $7 \mathrm{Bb}$ and $\mathrm{c}$ ), while $\mathrm{B} 5 \Delta \mathrm{N}$ lacking the $\mathrm{N}$-terminus increased the sub-G1 population to $11.5 \%$ (Figure $7 \mathrm{Ba}$ ) which is significantly higher than the background value. This increase was repeatedly observed, suggesting that the potential activity of B5 to induce apoptosis is masked by the $\mathrm{N}$-terminal region which has no sequence homology with the corresponding region of Nip3. All the three B5 mutants had no effects on the induction of apoptosis by E1A (Figure 7Bd-f). However, apoptosis induced by Nip3 was significantly inhibited by coexpression with $\mathrm{B} 5 \Delta \mathrm{N}$ and $\mathrm{B} 5 \Delta \mathrm{M}$, but not by $\mathrm{B} 5 \Delta \mathrm{C}$ (Figure $7 \mathrm{Bg}-\mathrm{i}$ ), suggesting that $\mathrm{B} 5$ inhibits apoptosis induced by Nip3 through interaction with Nip3 at the C-terminal region. The extents of apoptosis inhibited by $\mathrm{B} 5 \Delta \mathrm{N}$ and $\mathrm{B} 5 \Delta \mathrm{M}$ were about $30 \%$ when calculated after subtraction of the background value and were similar to that caused by wild type B5.

\section{Discussion}

In the present study, cellular proteins that interact with adenovirus E1B19K protein were analyzed by isolating the cDNA clones using yeast two hybrid system. Analysis of the structural features of the B5 protein (B5) encoded by one of these clones (Figure 1) revealed that $\mathrm{B} 5$ contains the putative $\mathrm{BH} 3$ domain in the middle region and the transmembrane domain in the $\mathrm{C}$-terminal region, which is characteristic of the members of the Bcl-2 and E1B19K binding protein families. Through this putative transmembrane region, B5 homodimerizes and heterodimerizes tightly with Nip3, weakly with $\mathrm{E} 1 \mathrm{~B} 19 \mathrm{~K}$, but not with $\mathrm{Bcl}-2$. The homo- and heterodimerization may occur through hydrophobic interaction of the LXXLL motifs, ${ }^{25}$ since Nip3 has this motif and B5 has $\mathrm{LXXVL}$ sequence in their transmembrane regions. The $\mathrm{C}$ terminal transmembrane domain is also required to localize B5 to nuclear envelope, endoplasmic reticulum and mitochondria, as does Nip3 and the $\mathrm{Bcl}-2$ family members to these membranaceous structures. B5 has high sequence homology with Nip3 in the middle and $\mathrm{C}$-terminal regions, but has unique sequence in the $\mathrm{N}$-terminus.

The members of the Bcl-2 family are regulators of apoptosis and have function either to induce or to inhibit apoptosis. Most of these members have common conserved regions, designated $\mathrm{Bcl}-2$ homology region, $\mathrm{BH} 1$, $\mathrm{BH} 2$ and $\mathrm{BH} 3 .^{10,26,30} \mathrm{E} 1 \mathrm{~B} 19 \mathrm{~K}$ shares limited sequence homology with $\mathrm{Bcl}-2$ family members just before $\mathrm{BH} 2$ and in $\mathrm{BH} 1.5,6$ These homologous sequences are essential for suppression of apoptosis and to cooperate with E1A for transformation of rodent cells. Among these three $\mathrm{BH}$ domains, B5 contains only the BH3-like sequence in the middle of the molecule, as do another E1B19K binding proteins, Nip3 and Nbk/Bik. ${ }^{15,16,20}$ The $\mathrm{BH} 3$ domain has been shown to be sufficient for the interaction of Bax, a member of the Bcl-2 family with E1B19K and Bcl-2. ${ }^{10} \mathrm{BH} 3$ proteins are therefore supposed to cause cell death by interacting with and antagonizing anti-apoptotic members of the $\mathrm{Bcl}-2$ family through their $\mathrm{BH} 3$ domains. ${ }^{28}$

B5 itself has no ability to induce apoptosis, but inhibits apoptosis induced by Nip3, although the inhibition is weaker than that caused by E1B19K. The N-terminal deletion mutant, $\mathrm{B} 5 \Delta \mathrm{N}(\Delta 1-31)$, however, acquired the ability to induce apoptosis. Neither $\operatorname{B} 5 \Delta \mathrm{M}(\Delta 58-96)$ nor $\mathrm{B} 5 \Delta \mathrm{C}(\Delta 175-219)$ acquired this apoptotic ability, suggesting that the $\mathrm{N}$-terminal region, whose aa sequence differs from that of Nip3, masks the potential ability of B5 to induce apoptosis. All the BH3-containing proteins so far characterized, Nip3, Nbk/Bik and $\mathrm{Bid}^{29}$ are positive regulators of apoptotis, while B5 is a sole member which negatively regulates apoptosis. Similar negative role of the $\mathrm{N}$-terminal region on the induction of apoptosis has been reported with Bim, another $\mathrm{BH} 3$ protein containing the C-terminal transmembrane region. ${ }^{30}$ Bim has three isoforms, probably generated by alternative splicing, that progressively reduce the length of the $\mathrm{N}$-terminus. All three induce apoptosis, but the shortest Bims has the most potent activity, suggesting that the longer $\mathrm{N}$-termini might act negatively on the ability of the protein to induce apoptosis.

Apoptosis induced in KB cells by Nip3 occurred much stronger than did E1A, whereas B5 inhibited apoptosis induced by Nip3 but not apoptosis induced by E1A. The difference in the potency to induce apoptosis between $\mathrm{E} 1 \mathrm{~A}$ and Nip3, however, is partly dependent on the transfection period before cell harvest, since the induction of apoptosis by E1A takes much longer than Nip3. Although E1B19K protected apoptosis induced by Nip3 more effectively than that induced by $\mathrm{E} 1 \mathrm{~A}$, the protection also depends on the stage of the apoptotic process. Overexpression of $\mathrm{Bcl}-2$ delays the onset of apoptotis induced by Nip3 but the resistance is overcome by a longer period of incubation. ${ }^{20}$ The inhibition of Nip3-induced apoptosis by B5 is caused through the $\mathrm{C}$-terminal transmembrane region, since $\mathrm{B} 5 \Delta \mathrm{C}(\Delta 175-219)$ lost the ability to inhibit, but $\mathrm{B} 5 \Delta \mathrm{N}(\Delta 1-31)$ and $\mathrm{B} 5 \Delta \mathrm{M}(\Delta 58-96)$ did not. The Nip3 mutant lacking the $\mathrm{C}$-terminal transmembrane region does not dimerize and localize to mitochondria and loses the ability to induce apoptosis. ${ }^{20}$ These results suggest that apoptosis is regulated by the formation of homo- and hetero-dimers in the $\mathrm{E} 1 \mathrm{~B} 19 \mathrm{~K}$ binding $\mathrm{BH} 3$ proteins and by the ratio of positive regulators to negative regulators such as B5, in just the same way as the positive and negative regulators of the Bcl-2 family.

We previously showed that topoisomerase $I / \alpha$ is degraded via activation of a component(s) in the ubiquitin-proteasome pathway as one of the targets for $\mathrm{E} 1 \mathrm{~A}$ induced apoptosis in MA1 cells, a derivative of the $\mathrm{KB}$ 
cell line. ${ }^{21,22,31}$ The present study showed that the level of Nip3 in MA1 cells increased markedly, nearly tenfold, after induction of $\mathrm{E} 1 \mathrm{~A}$, while the level of $\mathrm{B} 5$ remained almost constant, suggesting that Nip3 might also be involved in executing apoptosis in MA1 cells.

\section{Materials and Methods}

\section{Cell culture}

The cell line MA1 was established from the human epidermoid carcinoma cell line KB by introducing the adenovirus E1A12S cDNA linked to the MMTV-LTR. ${ }^{21}$ MA1 cells express E1A12S in response to dexamethasone (dex) and induce apoptosis. KB, MA1 and COS7 cells were cultivated at $37^{\circ} \mathrm{C}$ in Dulbecco's modified Eagle's minimal essential medium with $10 \%$ fetal calf serum (FCS). Dialysed FCS was used for cultivation of MA1 cells.

\section{Construction of pGAD-MA1 cDNA library}

Poly $(A)^{+}$RNA was prepared from the mixture of MA1 cells treated with dex for $6,12,24,36$ and $48 \mathrm{~h}$ according to Okayama et al. $^{32}$ and reverse transcribed using the oligo(dT) primer with Xhol site. The RNA strand of the mRNA/cDNA hybrid was replaced by the corresponding DNA strand by using E. coli RNAseH, E. coli DNA polymerase I and $E$. coli DNA ligase, and the CDNA was ligated to EcoRI linkers after both termini were blunt-ended. After cleaved with EcoRI and Xhol, the cDNA (100 ng) was ligated to $100 \mathrm{ng}$ of the EcoRI/Sall-digested yeast expression plasmid, pGAD424 (Clontech) at $16^{\circ} \mathrm{C}$ for $48 \mathrm{~h}$. The ligated cDNA was extracted with phenol/chloroform, ultrafiltrated using micron 10 (MILLIPORE) and electrotransformed into Escherichia coli DH10B using the E. coli Pulser (Bio-Rad) to generate the pGAD-MA1 cDNA library. This library directs the expression of fused proteins between the transactivation domain of Gal 4 and cDNA-encoded polypeptides and replicates autonomously as plasmids in yeasts. The library contained $5.7 \times 10^{6}$ primary recombinants with an average cDNA size of about $1.5 \mathrm{~kb}$.

\section{Two hybrid screening}

The plasmid pGBT-E1B19K, which directs synthesis of the fused protein between the DNA-binding domain of Gal4 and E1B19K, was introduced into yeast strains HF7C and Y190 and two clones HF7CE1B19K and Y190-E1B19K were established. These tester strains were transformed with the pGAD-MA1 cDNA library and $\mathrm{his}^{+}, \mathrm{leu}^{+}$ transformants grown in S.D. medium containing either $1 \mathrm{mM}$ (for HF7C-E1B19K) or $25 \mathrm{mM}$ (for Y190-E1B19K) 3-AT were scored for $\beta$ galactosidase activity. Each colony was streaked on a square area printed on the nylon filter and incubated by placing the filter on S.D., $\mathrm{His}^{-}, 3-\mathrm{AT}$ agar medium at $30^{\circ} \mathrm{C}$ for 2 days. The filter was then dipped in liquid nitrogen and the colonies were frozen and thawed three times. The filter was overlaid onto Whatman $3 \mathrm{MM}$ filters that had been soaked in Z buffer (60 mM Na2HPO4.7H20, $60 \mathrm{mM} \mathrm{NaH2PO4.7H20,}$ $10 \mathrm{mM} \mathrm{KCl}, 1 \mathrm{mM} \mathrm{MgSO} 4 \cdot 7 \mathrm{H} 20,50 \mathrm{mM}$ 2-mercaptoethanol, $\mathrm{pH} 7.0$ ) containing $0.01 \% \mathrm{X}$-gal at $30^{\circ} \mathrm{C}$ for $1-2 \mathrm{~h}$. The positive clones that showed blue color were selected.

\section{Construction of expression vectors for B5 and its deletion derivatives}

B5 cDNA was synthesized by PCR with pGAD-B5 as the template, and the upstream sense primer from codons 1-7 fused to the Sall recognition sequence and the downstream antisense primer from codons 214-219 fused to the BamHI recognition sequence. The PCR product was cleaved with Sall and BamHI and inserted into the Sall$\mathrm{BamHI}$ site of $\mathrm{pH} \beta \mathrm{APr}-1^{33}$ to generate $\mathrm{pH} \beta \mathrm{APr}-\mathrm{B} 5$. $\mathrm{pH} \beta \mathrm{APr}-\mathrm{B} 5 \Delta \mathrm{C}$ which encodes $\mathrm{B} 5$ lacking the $\mathrm{C}$-terminal sequence from codons $175-$ 219 was constructed by synthesizing $B 5 \Delta C$ cDNA using the same upstream sense primer and the downstream antisense primer from codons 169-174 fused to the $B a m H I$ recognition sequence, and similarly inserting into $\mathrm{pH} \beta \mathrm{APr}-1$. $\mathrm{pH} \beta \mathrm{APr}-\mathrm{B} 5 \Delta \mathrm{N}$ which encodes B5 lacking the $\mathrm{N}$-terminal sequence from codons $1-31$ was constructed by synthesizing $B 5 \triangle N$ cDNA using the upstream sense primer from codons 32-38 fused to the Sall recognition sequence and the downstream primer used for construction of $\mathrm{pH} \beta \mathrm{APr}-\mathrm{B} 5$. For construction of $\mathrm{pH} \beta \mathrm{APr}-$ $\mathrm{B} 5 \Delta \mathrm{M}$, the N-terminal portion of B5 CDNA was synthesized with the same upstream primer used for synthesis of B5 CDNA and the downstream antisense primer from codons 51-57 fused to the EcoRI recognition sequence and inserted into the Sall-EcoRI site of pBluescript-KS ${ }^{+}$to generate pBluescript-B5N. The C-terminal portion of B5 cDNA was synthesized with the upstream sense primer from codons $97-103$ fused to the $E c o R I$ recognition sequence and the same downstream primer used for synthesis of B5 CDNA. The PCR product was cleaved with $E c o R I$ and $B a m H I$ and inserted into the EcoRI-BamHI site of pBluescript-B5N. The DNA was then cleaved with Sall and BamHI and the B5 $\triangle M$ DNA having a deletion between codons 58 and 96 was similarly inserted into $\mathrm{pH} \beta \mathrm{APr}-1$ to generate $\mathrm{pH} \beta \mathrm{APr}-\mathrm{B} 5 \Delta \mathrm{M}$.

The expression vectors for Flag epitope-tagged B5 and its deletion derivatives were constructed using PCXN2 which contains SV40 ori and the multi-cloning site (MCS) downstream of the CMV-1E enhancer and the chicken $\beta$-actin promoter. ${ }^{34}$ The B5 cDNA and its derivatives lacking either the $\mathrm{N}$-terminal half $(\triangle \mathrm{NM})$ or the $\mathrm{C}$-terminal region $(\Delta \mathrm{C})$ with the $E c o R I$ recognition sequence at both ends were synthesized by PCR and cloned into the EcoRI site within MCS. The vectors, pCXNFB5, pCXN-FB5 $\Delta C$ and pCXN-FB5 $\Delta$ NM express wild type (wt) B5, B5 lacking the $\mathrm{C}$-terminus from codons $188-219$ and B5 lacking the $\mathrm{N}$ terminal half from codons 1-119 with the Flag sequence at their $5^{\prime}$ ends, respectively

\section{Northern blot hybridization}

Total cellular RNA was prepared by the AGPC (acid guanidinium thiocyanate-phenol-chloroform) extraction method ${ }^{35}$ and poly(A)containing RNA was prepared by using Oligotex (dT)30. ${ }^{36}$ Aliquots of $3 \mu \mathrm{g}$ of poly $(\mathrm{A})^{+}$RNA were electrophoresed in $1.1 \%$ agarose gels in buffer containing 2.2 M formaldehyde, $20 \mathrm{mM}$ MOPS ( $\mathrm{pH} 7.0$ ), $8 \mathrm{mM}$ sodium acetate, $1 \mathrm{mM}$ EDTA and transferred to nylon membrane filters. RNAs were crosslinked by UV $(254 \mathrm{~mm})$ irradiation for $5 \mathrm{~min}$. Hybridization was performed first by preincubating the filters in $5 \times$ Denhardt's solution containing $50 \%$ formamide, $5 \times$ SSPE $(1 \times$ SSPE is $0.18 \mathrm{M}, \mathrm{NaCl} 10 \mathrm{mM} \mathrm{NaH} 2 \mathrm{PO} 4 \mathrm{pH} 7.0,1 \mathrm{mM}$ EDTA), $0.5 \%$ SDS and $100 \mu \mathrm{g} / \mathrm{ml}$ of denatured salmon sperm DNA at $42^{\circ} \mathrm{C}$ for $6 \mathrm{~h}$. Hybridization was carried out by adding $10^{6} \mathrm{c} . \mathrm{p} . \mathrm{m} . / \mathrm{ml}$ of ${ }^{32} \mathrm{P}$ labeled CDNA probes at $42^{\circ} \mathrm{C}$ for $16 \mathrm{~h}$. The $\mathrm{B} 5 \mathrm{cDNA}$ probe was synthesized by PCR using the upstream sense primer from codons $1-$ 5 and the downstream antisense primer from codons 57-53 in the presence of $\left[\alpha-{ }^{32} \mathrm{P}\right] \mathrm{dCTP}$. The cDNA probes for other mRNAs were prepared by labeling the whole cDNAs by using random priming DNA labeling system (Amersham).

\section{Immunoprecipitation}

COS7 cells $\left(1 \times 10^{5}\right.$ cells) were washed twice with DMEM and once with PBS and lysed in $1 \mathrm{ml}$ of lysis buffer $(50 \mathrm{mM}$ Tris- $\mathrm{HCl} \mathrm{pH} \mathrm{7.4,}$ $150 \mathrm{mM} \mathrm{NaCl}, 0.1 \% \mathrm{NP} 40$ ) containing 20 units $/ \mathrm{ml}$ of aprotinin and 
$2 \mathrm{mM}$ PMSF. The lysate was centrifuged at $8000 \times g$ for $20 \mathrm{~min}$ and the supernatant was precleared by incubating with $20 \mu \mathrm{l}$ of protein GSepharose with rocking followed by a brief centrifugation. The supernatant was incubated with $3 \mu \mathrm{g}$ of anti-Flag antibody M5 at $4^{\circ} \mathrm{C}$ for $1 \mathrm{~h}$ and gently rocked after addition of $20 \mu \mathrm{l}$ protein GSepharose at $4^{\circ} \mathrm{C}$ for $1 \mathrm{~h}$. The immune complex was precipitated by centrifugation at $12000 \times g$ for $20 \mathrm{~s}$ and washed eight times with

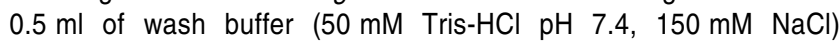
containing 20 units $/ \mathrm{ml}$ of aprotinin and $2 \mathrm{mM} \mathrm{PMSF}$.

\section{Western blotting}

Aliquots of COS7 cell lysates or its immunoprecipitates were electrophoresed on $12 \%$ polyacrylamide gels and proteins were transferred to Immobilon filters (Millipore). The filters were preincubated in immunoblotting diluent solution (5\% skim milk [Difco] and $0.1 \%$ Tween20 in PBS) at room temperature for $1 \mathrm{~h}$ and incubated with either anti-Flag antibody or anti HA-antibody at appropriate dilutions as indicated in the Figure legends at room temperature for $1 \mathrm{~h}$. The filters were washed three times in PBS containing $0.1 \%$ Tween20 and incubated with horseradish peroxidase (HRP)-conjugated anti-mouse IgG at a 1:200 dilution. Immune complexes were detected by ECL according to the manufacturer's protocol (Amersham Corp.).

\section{Immunofluorescence}

KB and COS7 cells cultivated on a LAb-Tek Tissue culture Chamber/ slide (Miles Scientific) were transfected with pCXN-FB5, pCXNFB5 $\triangle$ C or pCXN-FB5 $\Delta N M$ together with $\mathrm{pH} \beta A$ APr-E1B19k and fixed in freshly prepared aldehyde solution (4\% [vol/vol] paraformaldehyde in PBS) at room temperature for $10 \mathrm{~min}$. The fixed cells were washed in PBS, permeabilized in $0.1 \%$ Triton X-100 in PBS for 5 min and washed in PBS. To minimize nonspecific binding of antibodies, the cells were preincubated in $0.2 \mathrm{M}$ Tris-glycine, $\mathrm{pH} 7.4$ for $1 \mathrm{~h}$ at room temperature. The cells were covered with anti-Flag mouse monoclonal antibody M5 and anti-E1B19K rabbit polyclonal antibody at 1:250 dilutions and incubated at room temperature for $30 \mathrm{~min}$. The cells were then incubated with fluorescein isothiocyanate (FITC)-conjugated antimouse IgG goat antibody at a 1:2000 dilution and Texas Redconjugated anti-rabbit IgG donkey antibody at a 1:500 dilution at room temperature for $30 \mathrm{~min}$. In all the cases, the cells were washed extensively in Tris-buffered saline and mounted in $87 \%$ glycerol (Merck) containing 2.5\% 1,4-diazabicyclo [2,2,2] octane (Sigma).

\section{Flowcytometric Analysis}

Sparse cultures of KB cells in $3.5 \mathrm{~cm}$-dishes were transfected with combinations of the expression vectors (each $0.3 \mu \mathrm{g}$ ) $\mathrm{pH} \beta \mathrm{APr}-\mathrm{B} 5$, $\mathrm{pH} \beta$ APr-Nip3, $\mathrm{pH} \beta \mathrm{APr}-\mathrm{E} 1 \mathrm{~A} 12 \mathrm{~S}$, and $\mathrm{pH} \beta \mathrm{APr}-\mathrm{E} 1 \mathrm{~B} 19 \mathrm{~K}$ together with $0.1 \mu \mathrm{g}$ of pCMVCD $20^{37}$ by lipofection using LipofectAMINE PLUS ${ }^{\mathrm{TM}}$ transfection reagent (GIBCO-BRL). At $20 \mathrm{~h}$ post transfection, the cells were stained with FITC-labeled anti-CD20 antibody (B-B6, Biosource International). A set of the cells was transfected with control empty vector $\mathrm{pH} \beta \mathrm{APr}-1$ alone and similarly stained with anti-CD20 antibody to determine the background. After staining, the cells were fixed with $4 \%$ formaldehyde, treated in $0.1 \%$ Triton X-100 briefly to permeabilize the cells, and then stained with propidium iodide (PI) containing 1300 Kunitz unit $\mathrm{ml}^{-1} \mathrm{RNase} A$. The cells were analyzed for fluorescence intensity of FITC and PI by using a FACS-Calibour Flow-Cytometer and the cell quest program version 1.2 (Becton-Dickinson). The cell population that showed the fluorescence intensity over this background was gated and analyzed for cell cycle distribution.

\section{Acknowledgements}

We thank Dr. G. Chinnadurai for providing E1B19K mutant 90-6, Dr. E. White for E1B19K mutant pm51, Dr. S. Hashimoto for anti-E1B19K polyclonal antibody, Dr. J. Miyazaki for expression vector pCXN2 and Dr. E. Harlow for the CD20 expression vector.

\section{References}

1. White $E$ and Stillman B (1987) Expression of the adenovirus E1B mutant phenotypes is dependent on the host cell and on synthesis of E1A proteins. J. Virol. 61: 426-435

2. White E, Cipriani R, Sabbatini P and Denton A (1991) Adenovirus E1B 19kkilodalton protein overcomes the cytotoxicity of E1A proteins. J. Virol. 65: 29682978

3. White E, Sabbatini P, Debbas M, Wold WSM, Kusher DI and Gooding L (1992) The 19-kilodalton adenovirus $\mathrm{E} 1 \mathrm{~B}$ transforming protein inhibits programmed cell death and prevents cytolysis by tumor necrosis factor $\alpha$. Mol. Cell. Biol. 12: $2570-2580$

4. Rao L, Debbas M, Sabbatini Y, Hockenbery D, Korsmeyer SJ and White E (1992) The adenovirus $E 1 A$ proteins induce apoptosis which is inhibited by the E1B 19k and Bcl-2 proteins. Proc. Natl. Acad. Sci. USA 89: 7742-7746

5. Boyd JM, MalstromS, Subramanian T, Venkatesh LK, SchaeperU, Elangovan B, CD'Sa-Eipper and Chinnadurai G (1994) Adenovirus E1B 19 kDa and Bcl-2 proteins interact with a common set of cellular proteins. Cell 79: $341-351$

6. Chiou SK, Tseng CC, Rao L and White E (1994) Functional complementation of the adenovirus E1B 19k protein with Bcl-2 in the inhibition of apoptosis in infected cells. J. Virol. 68: 6553-6566

7. Hashimoto S, Ishii A and Yonehara S (1991) The E1B oncogene of adenovirus confers cellular resistance to cytotoxicity of tumor necrosis factor and monoclonal anti-Fas antibody. Int. Immunol. 3: 343-351

8. Gooding LR, Aquino L, Duerksen-Hughes PJ, Day D, Horton TM, Yei S and Wold WSM (1991) The E1B-19K protein of group C adenoviruses prevents cytolysis by tumor necrosis factor of human cells but not mouse cells. J. Virol. 65:3083-3094

9. White E and Cipriani R (1990) Role of adenovirus E1B proteins in transformation: altered organization of intermediate filaments in transformed cells that express the 19-kilodalton protein. Mol. Cell. Biol. 10: 120-130

10. Han J, Sabbatini P, Perez D, Rao L, Mohda D and White E (1996a) The E1B 19k protein functions as an apoptosis inhibitor by interacting with and inhibiting the p53-inducible and death-promoting Bax protein. Genes Dev. 10: 461-447

11. OltvaiZN, Milliman CL, Korsmeyer SJ (1993) Bcl-2 heterodimerizes in vivo with a conserved homolog, Bax, that accelerates programmed cell death. Cell 74: $609-619$

12. Farrow SN, White JHM, Martinou I, Raven T, Pun K-T, Grinham CJ, Martinou J-C and Brown R (1995) Cloning of a bcl-2 homologue by interaction with adenovirus E1B 19k. Nature 374: 731-733

13. Kiefer MC, Brauer MJ, Powers VC, Wu JJ, Umansky SR, Tomei LD and Barr PJ (1995) Modulation of apoptosis by the widely distributed Bcl-2 homologue Bak. Nature 374: 736-739

14. Chittenden T, Flemington C, Houghton AB, Ebb RG, Gallo GJ, Elangovan B, Chinnadurai $G$ and Lutz RJ (1995) A conserved domain in Bak, distinct from BH1 and $\mathrm{BH} 2$, mediates cell death and protein binding functions. EMBO J. 14: $5589-$ 5596

15. Boyd JM, Gallo GJ, Elangovan B, Houghton AB, Malstrom S, Avery BJ, Ebb RG, Subramanian T, Lutz RJ and Chinnadurai G (1995) Bik1, a novel death-inducing protein shares a distinct sequence motif with Bcl-2 family proteins and interacts with viral and cellular survival-promoting proteins. Oncogene 11: 1921-1928

16. Han J, Sabbatini P and White E. (1996b) Induction of apoptosis by human Nbk/ Bik, a BH3-containing protein that interacts with E1B 19k. Mol. Cell. Biol. 16: 5857-5864

17. Hockenbery DM, Nunez G, Minniman RD, Schreiber RB and Korsmeyer SJ (1990) Bcl-2 is inner mitochondrial membrane protein that blocks programmed cell death. Nature 348: $334-336$

18. Akao Y, Otsuki YS, Kataoka S, Ito Y and Tsujimoto Y (1994) Multiple subcellular localization of bcl-2: detection in nuclear outer membrane, endoplasmic reticulum and mitochondrial membrane. Cancer Res. 54: 2468-2471

19. Zhu W, Cowie A, Wasfy GW, Penn LZ, Leber B and Andrews DA (1996) Bcl-2 mutants with restricted subcellular location reveal spatially distinct pathways for apoptosis in different cell types. EMBO J. 15: 4130-4141 
20. Chen BG, Ray R, DubikD, Shi L, Cizeau J, Bleackly RC, Saxena S, Gietz RD and Greenberg AH (1997) The E1B 19K/Bcl2 binding protein Nip3 is a dimeric mitochondrial protein that activates apoptosis. J. Exp. Med. 186: 1975-1983

21. Nakajima T, Ohi N, Arai T, Nozaki N, Kikuchi A and Oda K (1995) Adenovirus E1A-induced apoptosis elicits a steep decrease in the topoisomerase ll $\alpha$ level during the latent phase. Oncogene 10:651-662

22. Nakajima T, Morita K, Ohi N, Arai T, Nozaki N, Kikuchi A, Osaka F, Yamao F and Oda K (1996) Degradation of topoisomerase ll $\alpha$ during adenovirus E1A-induced apoptosis is mediated by the activation of the ubiquitin proteolysis system. J. Biol. Chem. 271: 24842-24849

23. Sattler M, Liang H, Nettesheim D, Meadows RP, Harlan JE, Eberstadtr M, Yoon HS, Shuker SB, Chang BS, Minn AJ, Thompson CB and Fesik SW (1997) Structure of Bcl-XL-Bak peptide complex: recognition between regulators of apoptosis. Science 275: 983-986

24. Chinnadurai $G$ (1983) Adenovirus $2 \mathrm{Ip}^{+}$locus codes for a 19kd tumor antigen that plays an essential role in cell transformation. Cell 33: 759-766

25. McInerney EM, Rose DW, Flynn SE, Westin S, Mullen TM, Krones A, Inostroza J, Torchia J, Nolte RT, Assa-Munt N, Milburn MV, Glass CK and Rosenfeld MG (1998) Determinants of coactivator LXXLL motif specificity in nuclear receptor transcriptional activation. Genes Dev. 12: 3357-3368

26. Williams GT and Smith CA (1993) Molecular regulation of apoptosis: genetic controls on cell death. Cell 74: 777-779

27. Oltvai ZN and Korsmeyer SJ (1994) Checkpoints of dueling dimers foil death wishes. Cell 79: 189-192

28. Kelekar A and Thompson CB (1998) Bcl-2-family proteins: the role of the $\mathrm{BH} 3$ domain in apoptosis. Trends Cell Biol. 8: 324-330
29. Wang K, Yin XM, Chao DT, Milliman CL and Korsmeyer SJ (1996) BID: a novel BH3 domain-only death agonist. Genes Dev. 10: 2859-2869

30. O'Connor L, Strasser A, O'Reilly LA, Hausmann G, Adams JM, Cory S and Huang DC (1998) Bim: a novel member of the Bcl-2 family that promotes apoptosis. EMBO J. 17: $384-395$

31. Nakajima T, Kimura M, Kuroda K, Tanaka M, Kikuchi A, Seino H, Yamao F and Oda K (1997) Induction of ubiquitin conjugating enzyme activity for degradation of topoisomerase $11 \alpha$ during adenovirus E1A-induced apoptosis. Biochem. Biophys. Res. Commun. 239: 823-829

32. Okayama H, Kawaichi M, Brownstein M, Lee T, Yokota T and Arai K (1987) Highefficiency cloning of full-length cDNA; Construction and screening of cDNA expression libraries for mammalian cells. Methods in Enzymology 154: 3-28

33. Gunning P, Leavitt J, Muscat G, Ng SY and Kedes L (1987) A human $\mathscr{B}$-actin expression vector system directs high-level accumulation of antisense transcripts. Proc. Natl. Acad. Sci. USA 84: 4831-4835

34. Niwa H, Yamamura K and Miyazaki J (1991) Efficient selection for highexpression transfectants with a novel eukaryotic vector. Gene 108: 193-200

35. Chomczynski Pand SacchiN (1987) Single-step method of RNA isolation by acid guanidinium thiocyanate-phenol-chloroform extraction. Anal. Biochem. 162: $156-159$

36. Hara E, Furuichi $Y$ and Oda K (1995) Subtractive cDNA cloning using oligo(dT)30-latex and PCR. PCR in Neuroscience, In: Methods in Neurosciences, In Gobinda Sarker, (ed) San Diego: Academic Press pp. 262-276

37. Zhu L, van den Heuvel S, Helin K, Fattaey A, Ewen M, Livingston D, Dyson N and Harlow E (1993) Inhibition of cell proliferation by p107, a relative of the retinoblastoma protein. Gene Dev. 7: 1111-1125 